\title{
SME Growth in a Recession: What Does a Growing Business Tell?
}

\author{
Milan Gyanwali \\ De Montfort University, Leicester, England \\ Email: milan.gyanwali@dmu.ac.uk
}

How to cite this paper: Gyanwali, M. (2020) SME Growth in a Recession: What Does a Growing Business Tell? Open Journal of Business and Management, 8, 208-230. https://doi.org/10.4236/ojbm.2020.81013

Received: September 13, 2019

Accepted: December 21, 2019

Published: December 24, 2019

Copyright ( 2020 by author(s) and Scientific Research Publishing Inc. This work is licensed under the Creative Commons Attribution International License (CC BY 4.0).

http://creativecommons.org/licenses/by/4.0/

(c) () Open Access

\begin{abstract}
This article talks about growing small businesses in a recession and examines management strategies that made the company grow. Recessionary periods are accepted tough for small and medium enterprises (SMEs) to survive and grow, yet some do. SME performance is discussed associating with different factors including barriers, business characteristics, owner-manager lifestyle and networks. Prior studies have a significant contribution in exploring aggregate SME growth phenomena, but there is a little understanding of how SMEs grow in the recessionary periods. This study used a pluralist methodology with the participant action research as a primary approach, case study as a design and mix-method strategy to collect and analyse data. The research is dominant by qualitative research where such data were collected from a series of informal interviews and observation. Similarly, quantitative data such as business records and financial information were gathered from primary and secondary sources. The case study firm implemented two management strategies: learning in the organisation and restructuring the organisation to achieve growth during the recession of 2008-2009. Even though the precise impact of these strategies is challenging to establish, both learning and restructuring strategies were making the firm grow in the recession of 2008-2009. Since SMEs operate in a context, any "ready-to-use" and "one-size-fits-all" strategies and advice do not help individual businesses grow. This paper will be of interest to all the people who are involved in making the SMEs grow in recessionary periods.
\end{abstract}

\section{Keywords}

SMEs, Business Growth, Recession, Action Research

\section{Introduction}

It has been a decade of the 2008-2009 recession, but the stories of success and 
failure are not faded yet. During the recession, the most prevalent stories were about the credit crunch, business closure, increased unemployment and reduced annual turnover. The stories, less commonly shared, were about business growth, new business opportunities and growing market share. These contradictory stories encourage to investigate why and how some small and medium enterprises (SMEs) grow while others fail [1]. This article is one such attempt.

However, going into the topic of what makes SMEs grow in a recession, it is essential to understand three phenomena: SMEs and their contribution to the national economy, the 2008-2009 recession and its impact on SMEs and the case study firm.

SMEs and their contribution: Why should one research SME growth phenomena? It is vital to research SMEs, as they are the backbone of the national economy. The strands of literature uncover such importance for reducing unemployment and generating economy [2] [3] [4]. It is also identified that SMEs and national economies work in a dyadic relationship, where government helps SMEs grow, and SMEs help government for financial strength.

However, understanding the SME sector is quite complex. Various attempts were made to define and describe SMEs following the Bolton Committee Report in 1971. The SMEs, as they are known today, were not understood in the past. In some periods, SMEs were known as shopkeepers, and in other times, they were known as small businesses [5]. Furthermore, the standards used to define and describe SMEs were different as they were used to serve the local/national requirements having a little agreement on the understandings. This is reflected in the Bolton attempts too as they found it difficult to capture all SMEs using a single quantifiable measure. So, they considered the economic definition to characterise businesses and statistical definition to categorise them [6]. Some examples of business characters are management style, ownership and financial structure to separate small firms from larger ones [7] [8].

In the UK, the Department of Trade and Industry defines businesses using three standards: annual turnover, balance sheet amount, and the number of employees [9]. Any business is considered small if it has less than $£ 6.5$ million annual turnover, less than $£ 3.26$ million balance sheet amount and less than 50 employees. Similarly, the businesses with less than $£ 25.9$ million turnover, less than $£ 12.9$ million balance sheet amount and less than 250 employees are categorised as medium enterprises. These measures, for example, have a slight variation with the EU and clash with the USA [10] [11].

Regardless of how SMEs are defined or described, SMEs play a vital role in the national economies. In the UK, they account for more than 99 percent of total businesses, provide more than 59 percent of the total private sector employment and contribute about 50 percent of the total national turnover [12]. These facts justify the importance of studying SME performance phenomena in general, and SME growth during the recessionary periods in particular, when SME growth becomes questionable.

The 2008-2009 recession and its impact: The recession was the result of the 
US subprime market that burst in 2008. Any bailout efforts could not resolve the issue completely. Thus, the impact of banking burst spread around the world affecting the major economies including USA, Japan, China, Australia and New Zealand [13] [14]. Notably, the IMF [15] recognised this crisis as the deepest and longest since the 1930s.

During the recession, the UK was facing a tough economic situation with problems across many sectors [16]. Market contraction and increased unemployment were apparent as a consequence [17]. There was a most significant fall in the number of businesses since 1993 [18] where the unemployment increased by 2 per cent [19]. Moreover, 58 per cent of SMEs were severely affected [20]; 40 per cent of businesses experienced a fall in employment; 50 per cent of businesses had a fall in sales [21]. The economic adversity was hitting harder for SMEs compared to the larger firms, particularly the ones which were least prepared to cope with turbulent economic conditions [22].

In contrast, some businesses were growing during the recession. Some studies claim that the suitability of recession to grow [23] which is backed up by Rae [24] who finds some improvement in quality and business performance during the recessions. Similarly, Gulati et al. [25] identify nine per cent of the businesses were doing better in the recessionary period. The growers were among the ones having human capital [26]. This highlights the importance of identifying the appropriate approach for SME growth.

The case study firm: Why has Sharon Taxis become the intent of this research? As mentioned earlier, Sharon Taxis (the case study firm) is one of the nine percenters that achieved growth in the recession of 2008-09. This is one of three reasons. The second reason relates to the accessibility of research. It has been noticed that getting access to the business data and activities is challenging - see Curran and Blackburn [4]. In spite of SME limitations, Sharon Taxis offered business activities and data for research and also provided two people to ease the research process. Finally, the owner-manager was interested in identifying what was making the business grow.

A brief story of the case study firm starts in 2004 when Chris, the new owner-manager, acquired Sharon Taxis. This taxi firm was in operation as a private hire company since 1986 . Then in 2005, he bought another taxi company named Anthony Van Rentals. These two firms were merged in 2006 when Chris also established Anthony Garage to cater maintenance services to their vehicles. Chris made a huge investment in 2007 by buying 25 new taxicabs. In 2011, the owner-manager opened Anthony Garage with two servicing ramps. Sharon Taxis mainly provided taxi service during the recession, whereas Anthony Garage extended vehicle maintenance services to the public [27]. Thus, this research mainly focuses on the taxi business that was in operation during the recession.

In addition to the recession, few other things were also playing a negative role in business growth. For example, Sharon Taxis lost the transport contract from the local council; taxi licence was deregulated which attracted new entrants; new regulation forced to buy new vehicles. Despite these unexpected changes, the 
case study firm continued to perform better in terms of annual turnover, balance sheet amount, customers and employees.

These reasons, perhaps, justify the selection of Sharon Taxis for researching growth phenomena in the recession of 2008-09. This is the mater of interest to find out what do the growers do to achieve growth? Thus, this paper attempts to find business growth phenomena during the recession.

To present the discussion, this article has been divided into five sections. Following the introduction, the second section looks at the literature in the field of SMEs and business performance. In particular, it focuses on the complexities and challenges of SME growth. Similarly, the third section outlines how the pluralist methodology was used to investigate the case study firm and its growth phenomena in a recession. The results and analysis are presented in section four. This section is divided into three subsections - business performance, interpretation of strategies, and recommended strategies. The final section concludes this article and recommends strategies for business growth in a recession.

\section{Literature Review}

Since the publication of the Bolton Report in 1971, the SME sector has received significant attention for research [5]. SME contribution on employment creation and economy generation is highly valued which made to accept SMEs as the backbone for the national economy. Despite this fact, researching SME sector presents multiple complexities that lie around the availability and accessibility of data, availability of owner-manager for research and value of new knowledge to the company, see Curran and Blackburn [4], Storey [28].

When it comes to researching the individual SMEs and their growth phenomena, it adds a layer of complexity in the knowledge of defining SMEs, measuring growth, growth-making strategies and growth-affecting factors. On top of this, contextual factors add more challenges of precision in the number of SMEs and their overall contribution. Thus, this section uncovers three aspects: measuring business growth, growth-making strategies and growth-affecting factors. These aspects are discussed in general and also in the context of recession.

\subsection{Measuring Business Growth}

Measuring business performance has never been easy, as the performance is measured for different purposes. As such, different indicators are used to fulfil their requirements. The government officials tend to use the tax payments and employee numbers whereas owner-managers are more interested in profit, see Jarvis et al. [29]. Generally speaking, there are two approaches to measuring business performance objective (quantitative) and subjective (qualitative). Objective measures make it easy to quantify the changes. However, selecting and relying on them are challenging as they involve multiple choices such as absolute or relative growth, sales or profit growth, steady overall or merger/acquisition growth [30] [31] [32]. These measures have some sort of paradox which may provide contradictory results. 
In contrast, subjective measures are based on the opinions of individuals. Business growth for one may not be necessarily a growth for others. These rather different propositions make it difficult to come to the consensus of performance [29]. The terms like growth, development, sustain and success add an additional layer of complexity in measuring business performance. Thus, the dilemma of business growth straddles between measuring indicators, units of measurement, the person measuring growth and the process involved

In the literature, business growth has been entangled with terms such as financial performance [33], sustainability [34] [35], success [36], employee development [37], market expansion, market share, number of customers, and return on capital investment [38]. It is also confirmed that "business growth" carries perceptual meaning. For instance, the owner of a business may see a growth in terms of profit. However, for a manager, "growth" may mean exceeding the targets. These perceptual differences obviously refer to different growth-measuring indicators.

Therefore, it can be concluded that measuring the growth of a business using a single unit/aspect may provide a limited understanding and may not capture an overall picture. Blackburn et al. [39] also recommend multiple indicators to measure business performance which include both growth and developmental perspectives. It is important to consider Mao [40] who recommends to use quantity and quality of business overall. This signifies towards the use of both tangible as well as intangible changes. Therefore, as an academic, this could be resolved by mixing both quantitative and qualitative indicators such as employment, annual turnover, profit and market share.

\subsection{Growth-Making Strategies}

SMEs implement multiple strategies to grow their business. Some common strategies are Janus-faced, resource-based, strategic view, strategic business planning, investment-driven, product diversification, marketing, restructuring, and learning in the organisation. The effectiveness of each strategy depends on the business context. So, a little agreement on implementing strategies and their impacts are noticed.

Gulati et al. [25] emphasised the importance of a combined strategy that can be chosen from prevention-focused, promotion-focused, pragmatic and progressive. They warn that becoming too aggressive or too defensive will not help to grow businesses in the economic turbulences. The recommended combination comprises of operative effectiveness and market development along with asset investment strategies. In the times of financial contractions, implementing Janus-faced strategy cutting budgets in one area and investing in other areas is not easy, but this is accepted as a most effective in the recessionary periods.

The resource-based approach is not a new concept, of course. Penrose [41] recommends "resource-based" strategy to grow a business investing in fixed assets like machinery and making the business process more efficient or investing in people skills to boost their performance. In either case or a combination of 
both, businesses can achieve growth. Especially in the service industries, like the case study firm, soft skills help to grow a business and hard skills help to provide specialised services. Usually, small businesses do not invest in people and their soft/hard skills. Those lacking skills become the barriers to growth when employees are required to deal with customers and new technologies.

Stage-based strategies are also common for normal economic environments. Greiner [42] recommends five strategies aligning with the growth stages. These strategies need to match the business dimensions such as age and size, evolution and revolution stages, and growth rate. Similarly, authors like Churchill and Lewis [43], Gibb and Scott [44] also use strategic views, but the business-stages they discuss vary to each other. Interestingly, there are more than 100 business growth models, and a number of them use the growth-stage models to analyse business performance - see Levie and Lichtenstein [45], Merson [46]. Therefore, selecting the appropriate strategy for the specific business is tricky.

Also, a number of management strategies are associated with the growth of a business. Porter [47] recommends a number of them, including cost leadership, product differentiation, operation efficiency and focus. Similarly, Smallbone, et al. [48] find three strategies associated with the growth of manufacturing SMEs managing markets and products, production process and improvement, and labour productivity. Furthermore, Churchill and Lewis [49] recommend 13 recessionary strategies to sustain and grow small businesses. These strategies include monitoring collections, budget expenses and compliance, changing sales prices and stop selling to slow payers.

From the brief review of the literature on growth strategies, it is concluded that generic strategies have a less positive impact on business performance. Hence, the appropriate selection of strategies, along with growth-affecting factors, to the context is the only option to achieve business growth.

\subsection{Growth Affecting Factors}

In addition to the strategies, there are a number of factors that affect business performance. These factors could be divided into three groups owner-manager factors, business factors and other factors [8] [50] [51]. These factors are further discussed to see the relationship with business performance.

\subsubsection{Owner-Manager Factors}

In the UK, about 75 per cent of SMEs do not have any employees, and they are operated as a family business. That is, SME owner-managers are the player of their business - see Young [52], Andersson and Tell [53]. Therefore, the growth of a business depends on owner-managers and their characters such as growth intention, start-up objective, managing ability, lifestyle and family support, age, gender and leadership style.

Owner-managers of the growing business put the growth intention on top priority, but they also want to keep controlling them [54]. Some owner-managers also fear to lose control over the business whereas they do not want to grow their 
business because of the rewards/benefits they get from the government [7]. These contradictory behaviours make it difficult to understand whether these businesses have any intention to grow. Along with the willingness, the owner-manager need to have ability and motivation to manage change [55] [56] [57]. If owner-managers lack such characters, the business will not achieve growth.

A handful of literature associate business performance with age and gender. Some of them claim that the firms established and operated by younger owner-managers grow faster compared to the older owner-managers [58] [59]. Similarly, Cliff [60] and Singh et al. [61] find an association of gender in business performance. They notice the businesses owned by male grow faster than businesses owned by the females. However, businesses owned by females are more successful despite the fact that the growth is slow.

Singh et al. [61] also look at the business performance associating the academic background and claim that businesses owned by university graduates are more successful. However, when it comes to the experience, the context-specific experience is more valuable than the experienced gained in different organisations [62] [63].

Moreover, Delmar [64] finds a positive association between business growth and owner-manager characters. Similarly, Majumdar [65] finds entrepreneurial vision more important to achieve growth which is similar to the argument of Curran and Blackburn [66] who see business growth associating with intention and objective when the firm was formed. The discussion of characters does not stop here, there is more in the literature that includes leadership style, decision-making process, learning attitude and discretionary behaviour [67] [68] [69] [70] [71].

Thus, the literature on the owner-manager factors makes it clear that SME performance is very much dependent on the person leading the business.

\subsubsection{Business Factors}

There are some business characters such as age and size, location, products/services and business processes that affect business performance. A number of efforts are made to establish such links between business factors and their performance. Blackburn et al. [39] find an association of age and size to business performance. Age has both positive and negative association with growth. The shutdown rate of the younger firms is higher compared to the older ones, whereas the younger firms grow faster at an early age. It is also noticed that young firms are riskiest ones as 50 per cent of new start-ups shutdown within three years and 60 per cent close by ten years of their age [72] [73]. Business size also has something to do with business performance. Hamilton [74] finds a positive association, but he notices the importance of employment size.

The location is another factor which is discussed to relate the success of a small business [75] [76] [77]. It is particularly important because the location plays a major role in transporting time and cost, availability of human resources, 
availability of physical resources, and backward-foreward linkage. Similarly, the business process has something to do with business performance. According to Kitching et al. [14], performing businesses adopt the product or market diversification strategy and align with organisation-works whereas Zhao et al. [78] and Brink [79] link business growth with the networks of connections.

The review of business factors reveals that business performance is significantly affected by the business characters. However, individual businesses operate in a distinct situation, so identifying which one is more important is the matter of context.

\subsubsection{Other Factors}

Beyond business and owner-manager factors, there are some other factors that affect SME performance and three of them are particularly important. They are internal and external barriers, entry and exit barriers, and business advice and support. Interestingly, these factors have varied impact on business performance.

Internal and external barriers: internal barriers include funding, management capabilities, intention and motivation of growth, marketing and sales capacity, products and services. Similarly, external barriers are the ones that affect business externally. Some of the external barriers are the unavailability of employees, the high cost of capital, government tax, unfavourable legislation, lengthy bureaucratic process, competitive market structure and lack of infrastructure. These both internal and external barriers do not help to grow the business [80] [81] [82].

Regardless of their size and length, these barriers do not help businesses achieve performance. By studying SME performance in the UK between 1980 and 2002, Blackburn [83] concludes that the growth of a small business is more affected by the structural changes of the economic shift (external barrier) than organisational and institutional efforts (internal barrier).

Recently, uncertainty is discussed as one of the main obstacles to grow the business which can be either internal or external barrier. If the uncertainty increases for a longer period, the effects become prolonged on economic activity. If businesses find uncertainty, they use "wait-and-see" strategy which does not help businesses achieve performance [82].

Entry and exit barriers: these barriers are discussed in connection with business start-up, growth and closure. By analysing growing firms in the UK between 1980 and 1993, Murphy [84] concludes that low entry-barrier has low survival and high entry-barrier has high survival. The lower entry barriers increase the number of competitors which does not support to achieve business growth. Meanwhile, tough exit barriers stop owner-managers exiting from the business so the businesses will stay in the market making sector difficult to grow [85]. However, there is no straightforward solution for businesses that are already in the industry.

Business advice and support: Robson and Bennett [86] find a common prac- 
tice of obtaining external advice since the mid-1980s. Specifically, growth-driven businesses take advice in different stages of growth. This is supported by Trau [70] who finds a positive impact of "intervention-driven external advice" strategy. However, the advice alone does not help to grow a business that needs to be contextualised - see North et al. [87], Quinn [88]. This indicates that expert and contextualised advice has a positive impact on business performance.

Among the private sector businesses, advices from their accountants are most widely used which is followed by advice from bankers and lawyers. Friends and family members are other major sources of advice, especially when SMEs do not want to expose their information to outsiders. Advice from customers and suppliers also play a vital role to grow a business [86] [89]. Generally speaking, SMEs do not afford expert advice [37]. As a result, SMEs often try to get cheaper or free advice from non-expert sources. These advice should be checked carefully before implementing in the business, Department of Employment [89] suggests.

Usually, SMEs take advice in two situations first when SMEs find it difficult to sustain, and second when SMEs want to grow. By studying 16 micro-enterprises, Perren [90] concludes that businesses need tailored and timely support to achieve business growth. He also finds a complex pattern between independent growth factors and interim growth drivers. However, the impact of the advice remains unclear because of the complexity of input and other confounding factors. It is revealed that the advice received from like-minded people and trade organisations are vital. National and international trade fairs are more important to interact than the local and regional organisations. It is because people from national and international organisations share their business ideas more frankly than the people from local and regional businesses [91].

A brief review of business performance literature reveals that different strategies and factors play a role in business performance. However, there is a little understanding of how SMEs grow in the recessionary periods [92]. Most of the literature discusses the business performance in normal economic situations, and some of them discuss SME performance in the context of recession, but they take a large data leaving a gap in the literature of growing business in a recession. Thus, by researching a growing business in the recession of 2008-09, this paper investigates how SMEs could achieve growth in the recessionary periods.

Due to the ethical reasons, the name of people and firms are changed. To protect the research participants, the language was modified, where necessary, without changing the notion.

\section{Methodology}

Due to the limited resources and information that SMEs hold, it is very challenging to study SMEs [4] [8]. Also, understanding SMEs and their growth phenomena are socially constructed [93]. To get through these issues and study a growing business in a recession, this study employed a pluralist methodology combining with action research as the main approach [94] supplemented by the 
case study design (Yin, 2014). The combination of qualitative and quantitative methods is expected to provide the best possible results in researching a case study [95].

Among the different models of action researches, the combination of participant action research [94] and problem centred action research [96] was utilised. To follow the process of the action research, this study was divided into three phases. In the first phase, relevant data were collected and analysed. The qualitative data were analysed using content analysis whereas the quantitative data were analysed using descriptive statistics such as average. The output of data-analysis was compared with the sector and national changes [97]. In the second phase, strategies were made and discussed with the owner-manager. Similarly, in the final phase, the researcher left the field leaving strategies to implement in future [98] [99].

To avoid the drawbacks of action research such as researcher partiality and idiosyncratic decisions, a continuous process of observation, reflection and action was used throughout the research [100]. The partiality in data collection and analysis was illuminated by selecting research-participants form different divisions and levels. The information collected. Similarly, idiosyncrasy was maintained by observing the results of quantitative analysis with qualitative analysis. Two employees from the case study firm were involved in this research project who organised meetings with the owner-manager, provided secondary data and also helped to escape pitfalls.

The business, business processes and the owner-manager were investigated along with organisational efforts. Within the business aspect, location, size, age, number of employees and services were evaluated. The business process included strategy formation and implementation process, business management process, and HR process. The researcher also studied the owner-manager characters such as age, motivating factors, advice buying-in, lifestyle, leadership, intention and interest. As discussed in the literature review section, these factors are associated with business performance.

Since the case study firm implemented a number of strategies and organisational efforts, it was difficult to identify the impact of each activity and strategy. Thus, the data were collected from multiple sources. The business activity data were observed for three years between July 2013 and July 2016. These data included periodic reports, meeting minutes and other documents produced for government agencies and third parties.

Similarly, the owner-manager was shadowed for a month in January 2015. During the shadow period, the owner-manager actions such as business decisions, recruitment and selection activities, staff meeting and attending external meetings were observed and recorded in the field diary. The consistency in decision-making approaches, lifestyles and work-life balance were the main focus of shadowing. The actions taken by the owner-manager were discussed further to understand the strategic approaches. For example, after completing a meeting 
with under-performers, future plans and actions were discussed. Besides shadowing the owner-manager, individual character data were obtained from neighbouring business owners.

To identify the changes in the business, baseline data were collected. The baseline data included the number of employees, number of customers, number of jobs done in year and revenue generation. These baseline data helped to benchmark different indicators, measure the performance and analyse associated efforts. The qualitative data were gathered in the form of thick description such as observation, interaction, noticeboard notes, and semi-structured interviews with 19 research participants [101]. Similarly, quantitative data were drawn from financial reports and the number of customers and employees.

A series of interviews were conducted with Chris (the owner-manager of the case study firm) and his employees to gather information about growth intention, business processes and strategy formation and implementation processes. Organisational efforts were explored by conducting informal and unstructured interviews with the owner-manager, neighbouring business owners and employees. Data from trade organisations were also gathered by attending meetings and exploring publicly available data. Likewise, data for taxi regulations were collected from the local council through correspondence and telephone interviews.

The data about similar service providers in the study area were collected to find out their impacts on the case study firm. Such data were drawn from the Yellow Pages, Thomson Local, Companies House, local council and owner-manager. The data collected from different sources were merged and sorted out to resolve the discrepancies between trade names and registered names. Similarly, start-up and shutdown data were obtained from Companies House. The market-share data were collected from the local council, case study firm and Companies House. These data were verified by counting the number of vehicles on the road. The taxicabs were counted in ten different points within the town and analysed by using descriptive statistics.

\section{Results and Discussion}

The performance of the case study firm provides evidence of SME growth in a recession and shows that business growth was the result of restructuring and learning strategies. Based on the findings, future growth strategies are recommended at the end of this section.

\subsection{Business Performance}

Due to the difficulty of understanding the case study firm as a whole, different components are discussed individually, and the results are combined afterwards.

\subsubsection{Growth Intention}

The growth intention plays a vital role in business performance [66] which can 
be derived from two sources: the firm and the owner-manager. The objectives of the case study firm do not show any intention of business growth. Instead, it focuses on quality. In their mission statement, it states “... we have vowed always to strive to offer the best taxi service ... This includes offering a large fleet of well-maintained vehicles with good drivers at a price lower than our competitors." However, the owner-manager shows an intention of growth. In a conversation, he showed the interest of covering the region. Actions such as buying additional vehicles, setting up a garage, increasing the number of ramps and investing in people are evidence of such intention. Even though some of these characters fall under portfolio entrepreneurship [102] [103].

\subsubsection{Business Performance}

By analysing both financial and non-financial indicators, it is revealed that the case study firm achieved growth. Despite fluctuations, overall growth was achieved in the long run. The turnover of the business in 2004-05 was $£ 107 \mathrm{k}$, increasing to $£ 147 \mathrm{k}$ in $2005-06$. By 2006-07, the turnover reached $£ 194 \mathrm{k}$ and jumped to $£ 992 \mathrm{k}$ in $2007-08$. The turnover increment of more than 400 per cent was achieved from 25 additional taxicabs bought in 2007. Despite the termination of the contract from local authority and taxi licence deregulation, the annual turnover grew and reached $£ 1.09$ million in 2008-09.

The firm was also growing in the non-financial terms, customers and employees. In 2004-05, the case study firm employed 15 livelihoods which reached 25 in 2005-06. The number in 2006-07 reached 40 employees, followed by 49 in 2007-08. It is interesting that nine additional employees managed to run 25 additional vehicles. At this time, the owner-manager trimmed some office staff and recruited drivers. After 2007-08, the growth in the number of employees was settled, and steady growth was achieved.

Similarly, the number of customers was also increased. $121 \mathrm{k}$ customers in 2004-05 reached $139 \mathrm{k}$ in 2005-06. This growth continued and reached $160 \mathrm{k}$ in 2006-07. In 2007-08 alone, $32 \mathrm{k}$ customers were increased. This increase is associated with the number of additional vehicles. Even during the recession, customers increased by 11 per cent and reached $234 \mathrm{k}$. It is revealed that the growth was gained from efficient employees as there were no other confounding factors associated with this growth. Then, steady growth has been achieved throughout, except in the years 2011-12 and 2013-14, when there was a drop in the number of customers by $3 \mathrm{k}$ and $2 \mathrm{k}$ respectively.

\subsubsection{Organisation Works and Customer-Drain Effect}

Even in the adverse environment, the case study continued to grow. Such growth was questioned whether the business performance was the result of the customer-drain effect. From the available information, it is confirmed that there was no such effect, as there were neither any similar businesses were shutdown, nor any businesses were moved away. There were no changes in the alternative services, service providers and population that may bring positive impact to the case study firm. 
Hence, it is confirmed that the organisational efforts made the business grow. The case study firm implemented changes in the organisation internally and externally. Internal changes included the simplification of business process, training employees for a specific task, consolidation of human and physical resources, investing in physical assets and diversification of products. External changes included the establishment of networks with trade organisations and business partners, supporting local clubs, schools and hospitals, and getting expert advice.

\subsubsection{Market-Share and Efficiency}

As mentioned earlier, organisational inputs have a positive impact on the business and the employees. To compare employee performance and market share, the total number of taxis, employees and market share data were analysed. There were only 118 taxis in the study area including 57 licensed Hackney Carriages and 61 Private Hire Vehicles [104]. However, out of 20 taxi firms [105], only ten taxi firms provide their service at a time.

Sharon Taxis has the highest contribution on the number of vehicles which accounts 38 per cent of total vehicles compared to 15 per cent of nearest competitor followed by 6 per cent (the second competitor) and 41 per cent by the rest. Similarly, the case study firm has the highest contribution to the number of drivers ( 44 per cent) followed by the nearest competitor ( 16 per cent) and 41 per cent by the rest. The case study firm is the busiest taxi service provider in the area, as 38 per cent vehicles and 44 per cent of drivers occupy more than 61 per cent of total market share. This information tells that the case study firm is the most efficient business among the competitors in the study area.

\subsubsection{The Owner-Manager Style}

The owner-manager uses a hands-on approach and is very friendly with employees and business advisors. He is good at deconstructing the models and ideas and picking the shiny parts and reconstructing to make them fit for his business. He was a rugby manager in a local school; he chaired a finance committee in another school; served as a governing member for a university. By working together with non-profit organisations, he learned to manage diverse organisations. Apart from this, Chris was creating business networks. He has all three skills technical, human and conceptual required for a manager and visioning skill required for a business leader.

\subsection{Interpretation of the Growth}

People in the case study firm are engaged in internal and external organisation works which were associated with business growth. However, the situation in the case study firm was noisy and complex to grasp all in a go owner-manager meeting senior employees, conducting performance evaluations, meeting business-partners and trade organisations, and working for charity organisations; employees delivering their services, participating training programmes, going out for marketing and establishing business networks. In the office, the new IT 
system is being installed, building work is taking place, and new equipment is being set up. In such a complex situation, two glimmering strategies were identified learning in the organisation and restructuring the organisation.

\subsubsection{Learning in the Organisation}

The owner-manager implements two learning strategies in the organisation formal and informal. The formal learning process includes training programmes, and the informal learning process includes staff meetings, performance evaluation and feedback. This learning process comprises three levels the owner-manager, senior and junior employees. Learning in the owner-manager level takes place through the transformation of skill and knowledge. The owner-manager picks up the successful models, and he simplifies them before implementing it. For example, Chris learned about the business excellence model while he was doing his MBA. Later, he implemented this model in the bank, and now he is using this in his business. If we look at these organisations where Chris implemented the business excellence model, they are not comparable in the sense of what services they provide and how they operate the business. It is interesting what Chris selected from the model and how he has implemented in the business. Chris picked up people aspect from the model and implemented by simplifying and contextualising it to the business.

... the main thing I learnt from City Bank was you need to treat your customers how you like to be treated. The business excellence model helped me to generate a modified version of customer care. In this model, there are two sides: enablers and results. Approximately what I am trying to focus on people using this shape. Chris

The owner-manager uses the word "people" to refer employees as enablers and the customers as results. The business is focused on employees and customers where the employees provide standard and quality services to fulfil the customers' demand. Moreover, learning for the senior and junior employees was made by transferring the skills and knowledge to their subordinates. Another way of learning at this level takes place through action learning activities. It is very interesting to find that action learning tools were practised even in small firms like Sharon Taxis.

Through the meeting and feedback system, skills and knowledge are transferred informally. The communication process in the case study firm has different layers with a chain of command that is not very common in other small businesses. Chris organises the meeting with senior employees once a week and conducts a performance evaluation for the business and employees. If there are any concerns, he involves experts such as HR advisor and business partners. Furthermore, there are other formal ways of sharing knowledge and developing skills that take place through online, supervised training, and in-house or away training. Employees in the case study firm feel they are getting opportunities to learn and accept the firm as a learning organisation. Following three interviews are examples of what the employees think about the firm. 
When I came to work here, Chris asked me to have an MoT licence. This is something I never had but wanted to do. To have the MoT licence, you need to have a Level-3 qualification, which I did not have. Within six months I did Level-3, I got an MoT licence, and I gained Level-3 Diagnostic. Then going forward, I also have done a hybrid course. Jason

I did NVQ in Level-2 and customer service course five years ago. I attended the First Aid training a couple of years ago. William

I have done First Aid and customer service training. They are very useful. I am listed for the Excel and AAT courses. I think these learning programmes will help me to understand the accounting system and the business, and it will allow me paying the drivers. Natalie

It is clear that the case study firm is a learning organisation, and it is providing learning opportunities to the employees. It is also apparent that the employees are developing their skills. If we look at the business performance and employee development pattern, it becomes obvious that the business has a positive impact on employee learning and development. Jason explicitly expresses this idea after attending a weeklong training.

In the time frame I am in, we doubled the turnover. We also had to extend the workshop because we needed more space that was purely down to the volume of work coming in. It was not down to the people, needing more space. We have only two more technicians than when we started. We were four and now six of us, but if we look at the number of customers, we used to have $1 \mathrm{k}$ a year to nearly $4 \mathrm{k}$ now. We are more efficient, if people are not efficient, we try every possible way to improve their performance.

Listening to Jason, it becomes obvious that employee efficiency was increased as a result of learning in the organisation. It is generally understood that the turnover is dependent on the volume of customers, sales price, and the number of transactions rather than on employee efficiency. However, growth is associated with employee efficiency which was gained in the case study firm.

\subsubsection{Restructuring the Organisation}

The case study firm was gone through change management in the case study firm involving three-stage restructuring processes. In the first stage, the owner-manager gathered information and introduced different systems such as auditing, performance management, and setting up the boundary and roles and responsibilities of the employees. In the second stage, the owner-manager implemented plans such as trimming the employees, making the business process efficient, and developing people. In the third stage, the restructuring process was evaluated.

When Chris acquired two taxi firms, he consolidated human and physical resources. Employees were trimmed, and their efficiency was boosted. "Reciprocal training" was launched to help employees understand the value and role of other employees. Consequently, some of the staff started doing marketing activities and driving taxis when they were less busy with their assigned work. This 
process helped to gain more profit. However, there was the effect of organisation works which was discussed earlier.

As a restructuring process, the case study firm introduced small changes such as cashing up, banking, driver contract, and the CRB check. The employees were sent for the training so they could be more efficient in their work. By investing in the business process and standardising the practice, the case study firm provided better services with fewer employees. To implement such changes in the organisation, Chris obtained expert advice. In a conversation, Natalie gives a brief account of changes in the organisation.

He got rid of lots of staff basically, the managers weren't doing what they were supposed to do. He introduced and implemented so many procedures such as cashing up, driver procedure, driver sheet, banking and meetings. It is organised a lot.

It is interesting to know "restructuring the organization" is an on-going process, and it is a part of further planning. These operational changes have given an impression of change in the organisation; even so, such changes are only small and bumpy. As a consequence of these changes, staff became more focused and result oriented.

I am applying three things: hard work, perspectives and very good planning. If you want to become successful, you need to put in hard work, and your perspectives must be very clear. Planning for me is about looking at what's going to happen in the market two-three-four years ahead and give time to adapt slowly. I am using experiences from outside of our business. Chris

From the discussion and observation, it is clear that Chris implements three things in the business clear objectives to achieve from the business, putting efforts to attain the goals, and have plans/alternative plans. Even though these terms have contextual meaning, and he did not give any example, these factors helped him restructure the organisation and gain additional turnover.

As a part of restructuring the organisation, the owner-manager made the business grow. He drew boundaries of employees and their work, bought advice from HR professional to develop, engage and retain his employees. He also obtained advice from accountants, banks and insurance providers that helped to reduce the expenses, increase the turnover, plan the business, and manage the finance. It is very interesting that the owner-manager never implemented any advice as he bought it. He reviewed, contextualised and simplified them before implementing in his company.

\subsection{Growth Strategies for Future}

Learning in the organisation and restructuring the organisation have positive impacts on business performance. However, growth affecting factors and strategies have an overlapping impact on business growth. Therefore, finding a clear boundary of management strategies and affecting factors are challenging. Even the factors that are effective in a context may not work in other contexts. Therefore, the selection of management strategies and factors to grow the business 
needs to be contextualised.

By looking at the growth pattern, the business is still achieving absolute growth. To grow further, the case study firm needs to implement both organic and non-organic growth strategies. To achieve organic growth, the firm needs to provide specialist services that increase the catchment area or diversify the services and get new customers for new services. If the firm chooses non-organic growth, it may extend the business by opening new branches at new sites or establish interdependent companies.

Regarding the selection of strategies, it depends upon the types of growth the firm wants to achieve. From the empirical research, it is revealed that the growth is achieved through management strategies such as learning and restructuring the organisation, and factors like marketing, simplification of business process, networking, consolidation of resources, and human resource management. However, management strategies and growth factors need to be contextualised.

\section{Conclusions}

This paper argues that SMEs achieve growth during the financial turbulence with appropriate strategies to the context. The owner-manager implemented learning and restructuring strategies to achieve growth in the recession of 2008-2009. The evidence shows that the growth is not only directly dependent on any one of these single strategies or factors, but it is achieved from multiple strategies, associated factors and the knock-on effect of the efforts.

The case study firm implemented a learning strategy to achieve growth. The main way of learning in the senior management level was attained through the transformation. Other employees were developed through formal training, informal meetings, online learning, and performance evaluation. Another way of learning was taking place through business advice. Instead of getting generic and standard advice, the case study firm invested for expert and contextual advice which obviously helped them grow. Restructuring the organisation was another strategy used in the case study firm physical resources were upgraded; human resources were developed; resources were consolidated. By developing the employees, work efficiency was improved which resulted in the business effectiveness. Beyond these, business networks and like-minded people helped the company improve marketing procedure, facilitate collaboration with other organisations and expand the catchment area.

From this empirical research, it is concluded that multiple strategies and growth-factors made the case study firm grow in the recession of 2008-2009. If the businesses are prepared to tackle adverse situation by implementing changes and learning from within the organisation, they grow throughout the operation including recessions. Even though the findings could not be generalised because of the nature of the study, the case study firm could implement findings in the future similar situations. Similarly, other owner-managers could apply the findings by contextualizing to their businesses; business support organisations could also use the results to understand the context before giving context-specific ad- 
vice.

To confirm the findings and make SMEs successful, further studies are required including the businesses from different sectors, types, sizes and operations.

\section{Conflicts of Interest}

The author declares no conflicts of interest regarding the publication of this paper.

\section{References}

[1] Gyanwali, M. (2018) SME Growth in a Recession. School of Business, University of Leicester, Leicester.

[2] Birch, D.G.W. (1979) The Job Generation Process. MIT Programme on Neighborhood and Regional Change for the Economic Development Administration, US Department of Commerce.

[3] Storey, D.J. (1994) Understanding the Small Business Sector. Routledge, London.

[4] Curran, J. and Blackburn, R.A. (2001) Researching the Small Enterprise. SAGE Publications Ltd., London. https://doi.org/10.4135/9781849209847

[5] Dannreuther, C. and Perren, L. (2013) The Political Economy of the Small Firm. Routledge, London. https://doi.org/10.4324/9780203644829

[6] Bolton, J.E. (1971) Report of the Committee of Enquiry on Small Firms. Bolton Report, HMSO, London.

[7] Coad, A. (2009) The Growth of Firms: A Survey of Theories and Empirical Evidence. Edward Elgar Publishing Ltd., Cheltenham.

[8] Storey, D.J. (2010) Understanding the Small Business Sector. Cengage Learning EMEA, Andover.

[9] Companies House (2006) Companies Act 2006. Department of Business Innovation and Skills, Companies House, London.

[10] US International Trade Commission (2010) Small and Medium-Sized Enterprises: Overview of Participation in US Exports. USITC Publication, USITC, Washington DC.

[11] European Commission (2005) The New SME Definition: User Guide and Model Declaration. Enterprise and Industry, OOPEC, Luxembourg.

[12] Rhodes, C. (2012) Small Business and the UK Economy. House of Commons, London.

[13] Sharma, D., Garg, S.K. and Sharma, C. (2011) Strategies for SMEs after Global Recession. Global Business and Management Research, 3, 58-66.

[14] Kitching, J., et al. (2011) Adapting to a Fragile Recovery: SME Responses to Recession and Post-Recession Performance. 34th Institute for Small Business and Entrepreneurship (ISBE) Annual Conference, Sustainable Futures: Enterprising Landscapes and Communities, Sheffield.

[15] IMF (2009) Crisis and Recovery. In: World Economic Outlook, International Monetary Fund, Washington DC.

[16] BBC (2009) Timeline: Credit Crunch to Downturn. http://news.bbc.co.uk/1/hi/7521250.stm

[17] Vaitilingam, R. (2013) Recession Britain: Findings from Economic and Social Re- 
search. ESRC, Swindon.

[18] ONS (2013) Business Demography, 2012. Statistical Bulletin.

http://www.ons.gov.uk/ons/dcp171778 340530.pdf

[19] ONS (2011) Quarterly National Accounts: Time Series Dataset Q4 2011. Statistical Bulletin.

http://www.ons.gov.uk/ons/rel/naa2/quarterly-national-accounts/q4-2011/stb---qua rterly-national-accounts-gdp-q4-2011.html

[20] Howes, G. (2008) Economic Downturn Starts to Bite SMEs. http://www.smeweb.com/index.php?option $=$ com content $\& v i e w=\operatorname{article\& id=678:ec}$ onomic-downturn-starts-to-bite-smes\&catid=56:news

[21] Cowling, M. and Liu, W. (2011) Business Growth, Access to Finance, and Performance Outcomes in the Recession. The Department of Business Innovation and Skills, Sheffield.

[22] OECD (2009) The Impact of the Global Crisis on SME and Entrepreneurship Financing and Policy Responses. OECD, Centre for Entrepreneurship, SMEs and Local Development, Paris.

[23] Price, L., Rae, D. and Cini, V. (2013) SME Perceptions of and Responses to the Recession. Journal of Small Business and Enterprise Development, 20, 484-502. https://doi.org/10.1108/JSBED-04-2013-0057

[24] Rae, D. (2011) How Do You Grow a Business in a Recession? Enterprising Matters eMagazine. http://www.isbe.org.uk/recession

[25] Gulati, R., Nohria, N. and Wohlgezogen, F. (2010) Roaring out of Recession. Harvard Business Review, 88, 62-69.

[26] Cowling, M., et al. (2015) What Really Happens to Small and Medium-Sized Enterprises in a Global Economic Recession? UK Evidence on Sales and Job Dynamics. International Small Business Journal, 33, 488-513. https://doi.org/10.1177/0266242613512513

[27] Ainsworth, M. (2011) KLM Taxis and Headlands Garage: Competitor Analysis, Customer Analysis, SWOT. Sustainable Business Growth.

[28] Storey, D.J. (2011) Optimism and Chance: The Elephants in the Entrepreneurship Room. International Small Business Journal, 29, 303-321. https://doi.org/10.1177/0266242611403871

[29] Jarvis, R., et al. (2000) The Use of Quantitative and Qualitative Criteria in the Measurement of Performance in Small Firms. Journal of Small Business and Enterprise Development, 7, 123-134. https://doi.org/10.1108/EUM0000000006834

[30] Delmar, F. and Davidsson, P. (1998) A Taxonomy of High-Growth Firms. In: Reynolds, P.D. and Bygrave, W.D., Eds., Frontiers of Entrepreneurship Research, Babson College, Wellesley, 399-413.

[31] Weinzimmer, L.G., Nystrom, P.C. and Freeman, S.J. (1998) Measuring Organizational Growth: Issues, Consequences and Guidelines. Journal of Management, 24, 235-262. https://doi.org/10.1177/014920639802400205

[32] Cooney, T.M. and Malinen, P. (2004) Firm Growth as a Research Issue. In: Cooney, T.M. and Malinen, P., Eds., XVIII RENT Conference, Managing Complexity and Change in SMEs, European Council for Small Business and Entrepreneurship (ECSB), Copenhagen, 4-17.

[33] Gibb, A. (1993) Key Factors in the Design of Policy Support for SME Development Process: An Overview. Entrepreneurship \& Regional Development, 5, 1-24. https://doi.org/10.1080/08985629300000001

[34] Johannisson, B. (1993) Designing Supportive Contexts for Emerging Enterprises. In: 
Karlsson, C., Johannisson, B. and Storey, D., Eds., Small Business Dynamics. International, National and Regional Perspectives, Routledge, London, 117-144.

[35] Stokes, D. and Wilson, N. (2006) Small Business Management and Entrepreneurship. 5th Edition, Thomson, London.

[36] Bartlett, W. (1994) Employment in Small Firms: Are Co-Operative Different? Evidence from Southern Europe. In: Atkinson, J. and Storey, D.J., Eds., Employment, the Small Firm and the Labour Market, Routledge, London, 256-287.

[37] Orser, B.J., Hogarth-Scott, S. and Wright, P. (1996) Enterprising Intention and Likelihood of Growth: A Predictive Model of Firm Performance. In: Enterprising Futures, Birmingham, 728-747.

[38] Hoy, F., McDougall, P.P. and D’Souza, D.E. (1994) Strategies and Environments of High-Growth Firms. In: Sexton, D.L. and Kasarda, J.D., Eds., The State of the Art of Entrepreneurship, PWS-Kent Publishing, Boston, 341-357.

[39] Blackburn, R.A., Hart, M. and Wainwright, T. (2013) Small Business Performance: Business, Strategy and Owner-Manager Characteristics. Journal of Small Business and Enterprise Development, 20, 8-27. https://doi.org/10.1108/14626001311298394

[40] Mao, H. (2009) Review on Enterprise Growth Theories. International Journal of Business and Management, 4, 20-23. https://doi.org/10.5539/ijbm.v4n8p20

[41] Penrose, E. (2009) The Theory of the Growth of the Firm. 4th Edition, Oxford University Press, Oxford.

[42] Greiner, L.E. (1972) Evolution and Revolution as Organizations Grow. Harvard Business Review, 50, 37-46.

[43] Churchill, N.C. and Lewis, V.L. (1983) The Five Stages of Small Business Growth. Harvard Business Review, 61, 30-50.

[44] Gibb, A. and Scott, M. (1985) Strategic Awareness, Personal Commitment and the Process of Planning in the Small Business. Journal of Management Studies, 22, 597-632. https://doi.org/10.1111/j.1467-6486.1985.tb00014.x

[45] Levie, J. and Lichtenstein, B.B. (2010) A Terminal Assessment of Stages Theory: Introducing a Dynamic Stages Approach to Entrepreneurship. Entrepreneurship Theory and Practice, 34, 317-350. https://doi.org/10.1111/j.1540-6520.2010.00377.x

[46] Merson, R. (2016) Growing a Business: Strategies for Leaders \& Entrepreneurs. Profile Books, London.

[47] Porter, M.E. (1985) Competitive Advantage: Creating and Sustaining Superior Performance. Free Press, New York.

[48] Smallbone, D., North, D. and Kalantardis, C. (1997) The Survival and Growth of Manufacturing SMEs in Remote Rural Areas in the 1990s. In: Ram, M., Deakins, D. and Smallbone, D., Eds., Small Firms. Enterprising Futures, Paul Chapman Publishing Ltd., London.

[49] Churchill, N.C. and Lewis, V.L. (1984) Lessons for Small Business from the Recession. Journal of Small Business Management, 22, 5-17.

[50] Nichter, S. and Goldmark, L. (2009) Small Firm Growth in Developing Countries. World Development, 37, 1453-1464. https://doi.org/10.1016/j.worlddev.2009.01.013

[51] Zhou, H. and de Wit, G. (2009) Determinants and Dimensions of Firm Growth. SCALES EIM Research Reports (H200903). https://doi.org/10.2139/ssrn.1443897

[52] Young, L. (2012) Make Business Your Business: Supporting the Start-Up and Development of Small Business. GOV UK, London.

[53] Andersson, S. and Tell, J. (2009) The Relationship between the Manager and 
Growth in Small Firms. Journal of Small Business and Enterprise Development, 16, 586-598. https://doi.org/10.1108/14626000911000938

[54] Hay, M. and Kamshad, K. (1994) Small Firm Growth: Intentions, Implementation and Impediments. Business Strategy Review, 5, 49-68.

https://doi.org/10.1111/j.1467-8616.1994.tb00166.x

[55] Blackburn, R.A., et al. (2009) Understanding the Challenges to Growth in Entrepreneurial Firms: Cases from the UK and USA. XIII RENT Conference, Budapest, 19-20 November 2009, 1-24.

[56] Delmar, F. and Wiklund, J. (2008) The Effect of Small Business Managers' Growth Motivation on Firm Growth: A Longitudinal Study. Entrepreneurship Theory and Practice, 32, 437-457. https://doi.org/10.1111/j.1540-6520.2008.00235.x

[57] Davidsson, P. (1991) Continued Entrepreneurship: Ability, Need and Opportunity as Determinants of Small Firm Growth. Journal of Business Venturing, 6, 405-429. https://doi.org/10.1016/0883-9026(91)90028-C

[58] Obeng, B.A., Robson, P.J.A. and Haugh, H. (2014) Strategic Entrepreneurship and Small Firm Growth in Ghana. International Small Business Journal, 32, 501-524. https://doi.org/10.1177/0266242612463946

[59] Barkham, R., et al. (1996) The Determinants of Small Firm Growth: An International Study in the UK 1986-90. Routledge, London.

[60] Cliff, J.E. (1998) Does One Size Fit All? Exploring the Relationship between Attitude towards Growth, Gender and Business Size. Journal of Business Venturing, 13, 523-542. https://doi.org/10.1016/S0883-9026(97)00071-2

[61] Singh, S.P., Reynolds, R.G. and Muhammad, S. (2001) A Gender-Based Performance Analysis of Micro and Small Enterprises in Java, Indonesia. Journal of Small Business Management, 39, 174-182. https://doi.org/10.1111/1540-627X.00016

[62] Cooney, T.M. (2012) Entrepreneurship Skills for Growth-Oriented Businesses. Skills Development for SMEs and Entrepreneurship, Copenhagen, 28 November 2012.

[63] Macpherson, A. (2005) Learning How to Grow: Resolving the Crisis Knowing. Technovation, 25, 1129-1140. https://doi.org/10.1016/j.technovation.2004.04.002

[64] Delmar, F. (1996) Entrepreneurial Behaviour and Business Performance. Stockholm School of Economics, EFI, The Economic Research Institute, Stockholm.

[65] Majumdar, S. (2008) Modelling Growth Strategy in Small Entrepreneurial Business Organisations. The Journal of Entrepreneurship, 17, 157-168. https://doi.org/10.1177/097135570801700204

[66] Curran, J. and Blackburn, R.A. (1994) Small Firm and Local Networks: The Death of the Local Economy? SAGE Publications Ltd., London.

[67] Vargas, I.M.R. (2014) Determinant Factors for Small Business to Achieve Innovation, High Performance and Competitiveness: Organizational Learning and Leadership Style. Procedia-Social and Behavioural Sciences, 169, 43-52. https://doi.org/10.1016/j.sbspro.2015.01.284

[68] Avolio, B.J. and Bass, B.M. (1991) The Full Range Leadership Development Programs: Basic and Advanced Manuals. Bass, Avolio Associates, New York.

[69] Baumol, W.J. (1959) Business Behavior, Value and Growth. Palgrave Macmillan, New York.

[70] Trau, F. (1996) Why Do Firms Grow? ESRC Centre for Business Research, University of Cambridge, Cambridge.

[71] Gilbert, B.A., McDougall, P. and Audretsch, D.B. (2006) New Venture Growth: A 
Review and Extension. Journal of Management, 32, 926-950. https://doi.org/10.1177/0149206306293860

[72] Slatter, S. (1992) Gambling on Growth: How to Manage the Small High-Tech Firm. John Wiley \& Sons, Chichester.

[73] Reid, S. and Garnsey, E. (1996) High Technology_High Risk? The Myth of the Fragile Firm. Research Papers in Management Studies, University of Cambridge, Cambridge.

[74] Hamilton, R.T. (2012) How Firms Grow and the Influence of Size and Age. International Small Business Journal, 30, 611-621. https://doi.org/10.1177/0266242610383446

[75] McPherson, M.A. (1996) Growth of Micro and Small Enterprises in Southern Africa. Journal of Development Economics, 48, 253-277. https://doi.org/10.1016/0304-3878(95)00027-5

[76] Smallbone, D., North, D. and Kalantardis, C. (1999) Adapting to Peripherality: A Study of Small Rural Manufacturing Firms in Northern England. Entrepreneurship \& Regional Development, 11, 109-127. https://doi.org/10.1080/089856299283227

[77] Teruel-Carrizosa, M. (2010) Why Do SMEs Grow? A Rejection of Gibrat's Law for Spanish Firms (1994-2002). In: Lenihan, H., Andreosso-O'Callaghan, B. and Hart, M., Eds., SMEs in a Globalised World: Survival and Growth Strategies on Europe's Geographical Periphery, Edward Elgar Publishing Ltd., Cheltenham, 19-46. https://doi.org/10.4337/9781849805353.00011

[78] Zhao, X.-Y., Frese, M. and Giardini, A. (2010) Business Owners' Network Size and Business Growth in China: The Role of Comprehensive Social Competency. Entrepreneurship \& Regional Development, 22, 675-705. https://doi.org/10.1080/08985620903171376

[79] Brink, T. (2011) What Connections in Networks of Private Entrepreneurs Are Related to Growth? Ager. Revista de Estudios Sobre Despoblacion Y Desarrollo Rural, Octobre-Sin Mes, 57-81.

[80] Barber, J., Metcalfe, J.S. and Porteous, M. (1989) Barriers to Growth in Small Firms. Routledge, London.

[81] Goldberg, M. and Palladini, E. (2008) Chile: A Strategy to Promote Innovative Small and Medium Enterprises. The World Bank.

[82] Bachmann, R., Elstner, S. and Sims, E.R. (2010) Uncertainty and Economic Activity: Evidence from Business Survey Data. NBER Working Paper Series, National Bureau of Economic Research, Cambridge, MA. https://doi.org/10.3386/w16143

[83] Blackburn, R. (2002) Small Business in the UK: From Hard Times to Great Expectations. The 22nd Japanese Annual Small Business Society (JASBS), Kawasaki, October 2002.

[84] Murphy, M. (1996) Small Business Management. Pitman Publishing, London.

[85] Jamehshooran, B.G., et al. (2011) The Past, Present and Future of Online Marketing. Interdisciplinary Journal of Contemporary Research in Business, 3, 585-606.

[86] Robson, P.J.A. and Bennett, R.J. (2000) SME Growth: The Relationship with Business Advice and External Collaboration. Small Business Economics, 15, 193-208. https://doi.org/10.1023/A:1008129012953

[87] North, J., Blackburn, R. and James, C. (1997) Reaching Small Business? Delivering Advice and Support to Small Business through Trade Bodies, In: Ram, M., Deakins, D. and Smallbone, D., Eds., Small Firms. Enterprising Futures, Paul Chapman Publishing Ltd., London, 121-135. 
[88] Quinn, J.M. (2001) Developing Growth Strategies for the Small-Business Owner. Journal of Financial Planning, 14, 62-70.

[89] Department of Employment (1991) Keys to Growth for Owner-Managers Seeking to Expand. Price Waterhouse and Department of Employment, London.

[90] Perren, L. (1999) Factors in the Growth of Micro-Enterprises (Part 1): Developing a Framework. Journal of Small Business and Enterprise Development, 6, 366-385. https://doi.org/10.1108/EUM0000000006691

[91] Denckels, R. and J. Lambrecht (1995) Networks and Small Business Growth: An Explanatory Model. Small Business Economics, 7, 273-289. https://doi.org/10.1007/BF01108617

[92] Pearce II, J.A. and S.C. Michael (2006) Strategies to Prevent Economic Recessions from Causing Business Failure. Business Horizons, 49, 201-209. https://doi.org/10.1016/j.bushor.2005.08.008

[93] Burr, V. (2015) Social Constructionism. 3rd Edition, Routledge, London. https://doi.org/10.4324/9781315715421

[94] Lewin, K. (1946) Action Research and Minority Problems. Journal of Social Issues, 2, 34-36. https://doi.org/10.1111/j.1540-4560.1946.tb02295.x

[95] Creswell, J.W. (2014) Research Design: Qualitative, Quantitative and Mixed Methods Approaches. SAGE Publications Ltd., London.

[96] Stringer, E.T. (2007) Action Research. 3rd Edition, SAGE Publications Ltd., London.

[97] Saunders, M.N.K., Lewis, P. and Thornhill, A. (2019) Research Methods for Business Students. 8th Edition, Pearson, London.

[98] Chein, I., Cook, S.W. and Harding, J. (1948) The Field of Action Research. American Psychologist, 3, 43-50. https://doi.org/10.1037/h0053515

[99] Susman, G.I. and Evered, R.D. (1978) An Assessment of the Scientific Merits of Action Research. Administrative Science Quarterly, 23, 582-603. https://doi.org/10.2307/2392581

[100] Kemmis, S. and McTaggart, R. (2000) Participatory Action Research. In: Denzin, N.K. and Lincoln, Y.S., Eds., Handbook of Qualitative Research, SAGE Publications Ltd., London.

[101] Adams, W.C. (2015) Conducting Semi-Structured Interviews. In: Wholey, J.S., Harty, H.P. and Newcomer, K.E., Eds., Handbook of Practical Program Evaluation, Jossey-Bass, San Francisco, 492-505. https://doi.org/10.1002/9781119171386.ch19

[102] Parker, S.C. (2014) Who Become Serial and Portfolio Entrepreneurs? Small Business Economics, 43, 887-898. https://doi.org/10.1007/s11187-014-9576-2

[103] Carter, S. and Ram, M. (2003) Reassessing Portfolio Entrepreneurship. Small Business Economics, 21, 371-380. https://doi.org/10.1023/A:1026115121083

[104] Vaughan, L. (2015) History of Taxi Regulation. M. Gyanwali, Kettering Borough Council.

[105] Ware, G. (2015) Business Information. M. Gyanwali, Companies House. 